\title{
Analisis Personal Branding Youtuber Gim : (Studi Fenomenologi Michael Souw)
}

\author{
Andrey Wibowo, Farid \\ Andreywibowo96@yahoo.com,farid@fikom.untar.ac.id \\ Fakultas Ilmu Komunikasi Universitas Tarumanagara
}

\begin{abstract}
As the development of the era of new digital media emerged, one of them was YouTube. YouTube is the largest video sharing site in the world, Users who make game content on YouTube are referred to as Youtuber Games. Michael Souw is one of the famous Youtuber Games. The purpose of this study was to find out Michael Souw's personal branding to reach audiences by using a personal branding component. This type of research is qualitative by using case studies with data collection methods namely in-depth interviews. There is a theory used in this study such as a component of personal branding, distinctive features, mass communication. The conclusion of this study is the personal branding strategy to reach the audience based on the personal branding component, namely the characteristics and abilities.
\end{abstract}

Keywords: Youtube, Michael Souw, Youtuber Game, Personal Branding.

\begin{abstract}
Abstrak
Seiring Perkembangan zaman muncul nya sebuah media baru digital, salah satunya YouTube. YouTube merupakan situs berbagi video terbesar di dunia, Pengguna yang membuat konten game di YouTube disebut sebagai Youtuber Game. Michael Souw merupakan salah satu Youtuber Game yang sudah cukup ternama. Tujuan dari penelitian ini adalah untuk mengetahui personal branding Michael Souw untuk meraih audience dengan menggunakan komponen personal branding. Jenis penelitian ini adalah kualitatif dengan menggunakan fenomenologi dengan metode pengumpulan data yaitu wawancara mendalam. Terdapat adanya teori yang digunakan dalam penelitian ini seperti personal branding, komponen personal branding, komunikasi massa. Kesimpulan dari penelitian ini adalah personal branding yang dilakukan Michael Souw untuk meraih audience berdasarkan komponen personal branding yaitu ciri khas dan kemampuan.
\end{abstract}

Kata kunci: Youtube, Michael Souw , Youtuber Game, Personal Branding.

\section{Pendahuluan}

Seiring dengan perkembangan zaman teknologi informasi dan komunikasi semakin berkembang dengan pesat, sebagian besar teknologi yang digambarkan sebagai media baru yaitu digital. Media baru merupakan istilah untuk mencakup kemunculan digital yang termaksud social network, blog, dan online forum yang biasanya menggunakan komputer sebagai medianya, tetapi seiring dengan kemajuan teknologi dapat menggunakan smartphone sebagai pengganti komputer. Smartphone memiliki keunggulan yang lebih yaitu dapat dengan mudah mengakses internet,media sosial dan untuk mendapatkan informasi dimanapun dan kapanpun. Media sosial menurut Dailey (2009:3) adalah konten online yang dibuat menggunakan teknologi penerbitan yang sangat mudah di akses serta terukur. Pada 
saat ini jejaring media sosial banyak sekali diminati oleh masyarakat salah satu adalah YouTube.

Media sosial YouTube adalah sebuah situs web berbagi video yang memungkinkan pengguna nya untuk dapat menonton jutaan video yang mereka sukai secara gratis yang diunggah dari seluruh bagian negara, selain itu masyrakat dapat membuat konten video apapun dan kemudian mengunggah video tersebut agar dapat berbagi dan disaksikan oleh masyarakat luas lainya. Salah satu konten video yang sangat populer dan banyak disukai oleh masyarakat di YouTube adalah video bermain game.

Game adalah permainan yang menggunakan media elektronik, merupakan sebuah hiburan berbentuk multimedia yang di buat semenarik mungkin agar pemain bisa mendapatkan sesuatu sehingga adanya kepuasaan batin. Terbukti game sudah sangat berkembang di kalangan masyarakat karena game masuk dalam daftar lomba yang di pertandingkan dalam Asian Games 2018 https://bolalob.com/read/88006/inilah-6-game-yang-dipertandingkan-di-esportsasian-games-2018.

Bermain game dapat untuk menambah dan mempertahankan ketenaran dengan cara membuat video atau merekam pada saat bermain game dengan melakukan penjelasan permainan game tersebut, memberikan tutorial untuk bermain game, memberikan informasi tentang game, dan lain-lain kemudian menggunggah video tersebut di YouTube. Dan salah satunya adalah Michael Souw seorang Youtuber Gaming yang sudah cukup terkenal di kalangan masyarakat khusus nya dikalangan anak milenial. Youtuber Game harus memiliki personal branding yang baik dengan tujuan agar dapat untuk meraih audience.

Rumusan masalah dan tujuan dalam penelitian ini adalah untuk mengetahui bagaimana personal branding yang dilakukan oleh Michael Souw untuk meraih audience. Menurut Dewi Haroen dalam buku Personal Branding Kunci Kesuksesan Berkiprah Di Dunia Politik, personal branding adalah proses membentuk persepsi masyarakat terhadap aspek-aspek yang dimiliki oleh seseorang, diantaranya adalah kepribadian, kemampuan, atau nilai-nilai dan bagaimana semua itu menimbulkan persepi positif dari masyarakat yang pada ahkirnya dapat digunakan sebagai alat pemasaran (Haroen, 2014:13). Personal branding memiliki fungsi dan tujuan yaitu untuk memperkenalkan dan mempertajam citra diri seseorang, memudahkan orang lain untuk mengingat kita, memudahkan dalam menentukan pilihan, berkarier secara fokus.

Dalam penelitian ini, personal branding yang dilakukan oleh Michael Souw adalah Membentuk dan mempunyai ciri khas yang bertujuan untuk membedakan dirinya dengan yang lainya serta membuat audience agar mudah dan selalu mengingat dirinya, selain itu strategi yang digunakan oleh Michael Souw ialah memiliki perilaku yang powerfull pada saat menjelaskan isi konten video nya dengan tujuan agar penontonya merasakan dedikasi tinggi yang telah ia berikan serta juga agar penonton tidak merasa bosan. Michael Souw juga memberikan penampilan yang goodlooking agar penonton nya merasa nyaman saat melihat dirinya. Selain itu diri nya memiliki prestasi di dalam game yang membuat penonton semakin yakin terhadap pesan serta informasi game yang disampaikan olehnya. 


\section{Metode Penelitian}

Pada penelitian ini, penulis menggunakan penelitian pendekatan kualitatif yang bersifat deskriptif. Penelitian yang dilakukan oleh penulis bertujuan untuk mengetahui personal branding youtuber game Michael Souw untuk meraih audience. Menurut Denzin dan Lincoln, 1987 dalam (Lexy J. Moleong). Penelitian kualitatif adalah penelitian yang menggunakan latar ilmiah, dengan maksud dapat menafsirkan fenomena yang terjadi yang melibatkan berbagai metode yang ada.

Metode yang digunakan oleh peneliti pada penelitian ini adalah peneliti menggunakan metode fenomenologi. Menurut Laksmi G. Siregar dalam buku Engkus Kuswarno yang berjudul Metode Penelitian Kualitatif Komunikasi Fenomenologi, Konsepsi, Pedoman dan Contoh Penelitianya menjelaskan bahwa terdapat tahapan yang harus dilakukan yakni tahapan perencanaan. Pada tahapan perencanaan, peneliti dapat mempersiapkan daftar pertanyaan dan dokumen, menjelaskan latar belakang penelitian serta memilih informan. John W.Creswell juga menambahkan bahwa terdapat tahapan pengumpulan data dalam penelitian fenomenologi. Pengumpulan data dapat dilakukan dengan wawancara (Kuswarno, 2009:66).

Fenomenologi digunakan untuk mengetahui dan mendalami suatu fenomena dengan mengumpulkan informasi dan data-data. Dengan demikian peneliti menggunakan studi kasus di dalam metode penelitian karena peneliti ingin mengetahui maupun untuk mengumpulkan informasi yang lebih mendalam pada kasus serta permasalahan yang ada.

Pada penelitian ini, peneliti menggunakan beberapa teknik pengumpulan data seperti: wawancara, studi kepustakaan dengan tujuan agar mendapatkan data serta informasi yang lebih dalam. Subjek penelitian ini adalah seorang Youtuber Game di YouTube yaitu Michael Souw. Objek penelitian ini adalah personal branding Michael Souw. Sehingga peneliti dapat lebih lagi untuk mendalami mengenai personal branding yang dilakukan oleh Michael Souw untuk meraih audience.

Teknik analisis data yang digunakan di dalam penelitian ini adalah teknik analisis data kualitatif menurut (Moleong, 2007:288) terdiri dari beberapa proses yaitu pengumpulan data, reduksi data, penyajian data, dan penarikan kesimpulan.

Sedangkan teknik keabsahan yang digunakan oleh peneliti dalam penelitian ini adalah dengan menggunakan teknik triangulasi. Triangulasi dapat diartikan sebagai pengecekan data dari berbagai sumber melalui berbagai macam cara dan waktu. Menurut Dwidjowinoto (Kriyantono,2010:72) ada beberapa macem triangulasi yang penting dalam uji keabsahan hasil penelitian yaitu triangulasi sumber, waktu, teori, periset, dan metode.

\section{Hasil Temuan dan Diskusi}

Michael Souw adalah salah satu Youtuber Game yang kerap dipanggil bosque oleh para penonton setia nya. Michael Souw lahir pada 10 Oktober 1993. Sebelum menjadi Youtuber game yang terkenal, Michael Souw memang sangat hobby bermain game yang dimulai sedari kecil. Setiap usai pulang sekolah Michael selalu bermain game namun ibu nya sama sekali tidak melarang maupun memarahi Michael, karena ibunya memberikan kebebasan selama itu bukan kegaiatan yang negatif. Tetapi Michael bukan hanya sekedar bermain game saja, karena Michael mendapatkan penghasilan dari bermain game dengan cara menjual akun game dan 
menyediakan jasa joki bermain game. Bahkan pada saat usia 13-14 tahun Michael pernah mendapatkan penghasilan tertinggi dari game sekitar 12-13 juta rupiah. Itulah merupakan salah satu faktor ibu Michael tidak melarang ia bermain game. Awal mula Michael berkarier di Youtube hanyalah sekedar mencoba dengan tujuan mencari teman untuk bermain game Mobile Legends yang pada waktu itu sedang sangat trend hingga saat ini.

Channel Youtube Michael Souw berdiri pada tanggal 4 Agustus 2017, Di dalam channel Youtube nya Michael Souw menyajikan konten game yang pada saat itu sedang trend yaitu game Mobile Legends. Michael Souw memilih membuat konten game di channel Youtube nya karena ia memang hobby dalam bermain game dan tujuan lainya untuk mendapatkan teman bermain game Mobile Legends. Video pertama yang dibuat lalu kemudian diunggah pada channel Youtube nya adalah video tentang game Mobile Legends pada tanggal 12 Agustus 2017 yang telah di saksikan sebanyak 23.147. Hingga saat ini Michael Souw telah membuat sebanyak 788 video game yang terdapat di dalam channel Youtube nya. Michael Souw dikenal sebagai Youtuber game Mobile Legends dan dapat dikatakan sebagai salah satu Youtuber game pertama yang membuat video tentang konten game Mobile Legends https://www.youtube.com/watch?v=Z3Bk5zhzM04. Selain membuat konten video secara offline, Michael Souw juga sering melakukan kegiatan siaran langsung atau live streaming pada saat bermain game Mobile Legends di Channel Youtube nya agar dapat melakukan interaksi dengan penontonya secara langsung. Hingga saat ini seluruh video Michael Souw di channel Youtube nya telah disaksikan sebanyak 239.189.469 x dan Michael Souw telah memiliki lebih dari 1.000.000 subscriber.

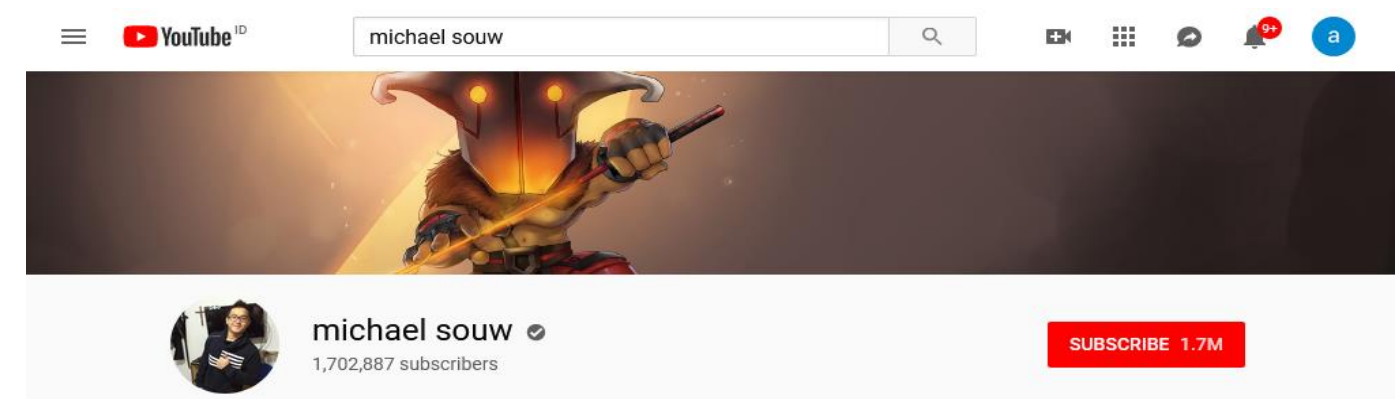

Gambar 1. Channel Youtube Michael Souw

Sumber : YouTube

Adapun hasil temuan dan diskusi yang terdapat dalam penelitian ini yang akan dibagi dalam konsep pembahasan yang yang telah dilakukan oleh peneliti dalam hal ini merupakan konten video Youtube merupakan perwujudan dari komunikasi massa yang berarti pesan yang dikomunikasikan melalui media massa pada sejumlah besar orang. Berdasarkan definisi tersebut, dapat diartikan bahwa komunikasi massa merujuk pada pesan (Bittner, 1980:10). Sesuai dengan salah satu fungsi komunikasi menurut Effendy (1993) yaitu fungsi informasi sebagai penyebar informasi bagi pembaca, pendengar maupun pemirsa, berbagai informasi yang dibutuhkan khalayak media massa yang bersangkutan sesuai dengan kepentinganya. Menggunakan media massa lebih mengetahui segala sesuatu di luar lingkungan. Konten video Michael Souw memenuhi fungsi komunikasi massa untuk memberikan informasi kepada audience sehingga mereka mendapatkan manfaat informasi terbaru 
seputar game, mendapatkan tutorial, dan juga tips dan trik dalam bermain game untuk dapat lebih mahir.

Setiap Youtuber harus memiliki personal branding yang baik agar dapat meraih audience dan juga untuk dapat bersaing dengan Youtuber lainya. Personal Branding merupakan proses membentuk persepsi masyarakat terhadap aspek-aspek yang dimiliki oleh seseorang, diantaranya adalah kepribadian, kemampuan, atau nilai-nilai dan bagaimana semua itu menimbulkan persepi positif dari masyarakat yang pada ahkirnya dapat digunakan sebagai alat pemasaran (Haroen, 2014). Personal branding yang dilakukan oleh Michael Souw dapat meraih audience. Secara tidak sadar personal branding Michael Souw berkembang berjalanya waktu, dapat dilihat bahwa tidak hanya perusahaan yang harus memiliki personal branding namum seseorang yang awalnya berasal dari bukan siapa-siapa dapat menjadi seseorang yang dikenal oleh banyak orang.

Komponen-komponen personal branding menurut Erwin dan Becky (2014) dalam buku Peronal Branding-Inc ada komponen-komponen yang dapat dijadikan sebagai bahan personal brand seseorang (Erwin dan Becky, 2014).

\section{Ciri Khas}

Ciri khas/keunikan yang dimiliki dapat menjadi komponen personal brand yang ingin kita bangun. Keunikan dapat menjadi pembeda seseorang jika dibandingkan dengan yang lainya. Jika keunikan yang diiliki dapat ditonjolkan dan dimanfaatkan semaksimal mungkin maka personal brand yang dimiliki pun akan semakin mudah dalam memahami dan mengingat seseorang dari sekian banyak orang yang memiliki keahlian untuk melakukan keunikanya. Dari hasil wawancara ini, dapat dilihat ciri khas yang dimiliki oleh Michael Souw adalah dia memiliki kata-kata yang sering digunakan untuk memanggil subscriber nya yaitu panggilan "Bosku", selain itu sering menggunakan kata-kata dan mempunyain tim game yaitu OBB " Orang beg* bebas" yang bertujuan untuk membuat penonton mudah dan selalu mengingat nya. (Kotler \& Keller, 2012) mendefinisikan brand atau merek adalah suatu nama, istilah, tanda, simbol, desain atau kombinasi dari semuanya yang dimaksudkan untuk mengidentifikasikan suatu barang maupun jasa dari satu penjual untuk membedakannya dari kompetitor lainya.

\section{Perilaku}

Dalam membangun personal brand, seseorang harus melakukan berbagai upaya untuk mendukung terbentuknya personal brand. Upaya yang dibangun dan berjalan secara konsisten. Michael Souw memiliki personal branding dalam menjelaskan isi video nya, ia melakukan secara semangat dan powerfull untuk membuat penonton tidak merasa jenuh serta bosan dan ingin membuat penonton merasakan dedikasi tinggi yang diberikan oleh Michael Souw.

\section{Penampilan}

Berkaitan dengan penampilan fisik seperti fashion, aksesoris, tata rambut, dll. Penampilan dapat mempengaruhi personal brand seseorang. Penampilan juga mempunyai peranan yang sangat penting, Seorang Youtuber harus memiliki penampilan yang rapih dan bersih dengan tujuan untuk membuat penonton merasa nyaman pada saat menonton video tersebut. 
4. Kemampuan dan keterampilan, Kekuatan

Kemampuan dan keterampilan merupakan kekuatan yang dimiliki dapat digunakan untuk menghasilkan sesuatu yang bermanfaat. Hal ini dimanfaatkan oleh Michael Souw dalam membuat konten video. Kemampuan dan keterampilan yang dimiliki oleh Michael Souw adalah pandai dan terampil dalam bermain game. Dan bukan hanya handal dalam bermain game, Michael Souw juga memiliki kemampuan untuk melakukan komunikasi, serta menjelaskan isi dari video nya tersebut pada saat bersamaan dengan bermain game. Tidak mudah untuk melakukan kegiatan tersebut secara bersamaan, dibutuhkan tingkat ke fokusan yang tinggi.

5. Prestasi

Mempunyai Prestasi lebih dapat menyakinkan audience terhadap pesan yang ingin disampaikan, Michael Souw pernah mendapatkan atau meraih prestasi dalam game Mobile Legends sebagai peringkat 1 hero terbaik sedunia. Mencapai atau membuat suatu prestasi tidak lah mudah dan butuh pengorbanan tetapi apabila telah mempunyai prestasi dapat menjadi salah satu komponen personal brand.

6. Tujuan

Harus memiliki sebuah tujuan dari personal branding yang dimiliki, serta juga berupaya agar dapat tercapai nya tujuan yang telah di tetapkan.

Selain itu personal branding juga memiliki fungsi dan tujuan, yaitu :

a. Mempertajam citra diri seseorang

Personal branding dapat membuat mempertajam citra diri seseorang, seperti yang di rasakan oleh Michael Souw, seiring dengan berjalan nya waktu Michael Souw memiliki personal branding untuk meraih audience, tetapi ia juga merasakan dampak positif dari strategi yang telah ia lakukan. Dapat disimpulkan Michael Souw merasakan manfaat yang ia dapat yaitu ia merasakan bahwa diri nya semakin berkembang serta skill komunikasi nya pun semakin meningkat dan membaik serta memudahkan diri nya dalam menyampaikan pesan kepada audience.

b. Memudahkan orang lain untuk mengingat

Michael Souw memiliki ciri khas yang membedakan diri nya dengan Youtuber Game lainya, yaitu Michael Souw sering berbicara menggunakan kata-kata "Boksu" serta juga untuk memberikan panggilan kepada subscriber yang menjadikan katakata tersebut sebagai ikon atau ciri khas yang dimilikinya dengan tujuan untuk membuat menonjol dibandingkan dengan lainya.

c. Berkarier secara fokus

Dengan dimilikinya personal branding, Michael Souw dapat berkarier secara fokus serta mempunyai suatu tujuan dengan target yang ingin dicapainya seperti yang dikutip oleh (Erwin dan Becky, 2014). Michael Souw dapat berkarier secara fokus karena ia membuat sesuatu yang ia suka tanpa adanya tekanan maupun paksaan. 


\section{Simpulan}

Personal branding yang telah dilakukan oleh Michael Souw dengan cara dalam membuat konten video game selalu mengikuti trend yang sedang populer di kalangan masyarakat Indonesia, selain itu Michael Souw selalu berusaha sebagai Youtuber Game pertama yang membuat konten video game yang sedang trend. Selain itu Michael Souw membentuk ciri khas diri nya agar selalu diingat oleh audience dan agar berbeda dengan yang lainya, serta dalam setiap video nya Michael Souw selalu menjelaskan secara powerfull untuk membuat audience tidak merasa bosan dan juga agar audience merasakan dedikasi tinggi yang diberikan oleh Michael Souw.

Tujuan Michael Souw untuk menyampaikan pesan dan manfaat kepada audience dalam setiap video nya telah tercapai karena telah membuat audience mendapatkan infromasi dan tutorial seputar game, karena menurut audience video nya memberikan informasi terbaru serta membuat ia semakin mahir dalam bermain game. Agar membuat audience untuk semakin yakin terhadap pesan yang disampaikan nya, Michael Souw telah memiliki prestasi sebagai peringkat 1 hero terbaik di seluruh dunia.

Michael Souw berusaha untuk mempunyai hubungan yang baik dengan audience dengan cara melakukan komunikasi serta memberikan giveaway kepada audience sebagai tanda ucapan terima kasih karena selalu mendukung dirinya.

\section{Ucapan Terima Kasih}

Penulis ingin menyampaikan ucapan terima kasih kepada seluruh narasumber yang telah bersedia untuk meluangkan waktu dalam melakukan proses wawancara dan memberikan informasi kepada penulis selama proses pengumpulan data untuk penelitian ini. Penulis juga berterimakasih kepada seluruh pihak yang telah turut membantu penelitian ini serta juga pihak Fakultas Ilmu Komunikasi Universitas Tarumanagara.

\section{Daftar Pustaka}

https://bolalob.com/read/88006/inilah-6-game-yang-dipertandingkan-di-esportsasian-games-2018.

Bittner. (1980). John R.Mass communication, an Introduction. Prentice-Hall

Effendy, Onong. Uchyana. 2006. Ilmu Komunikasi Teori dan Praktek. Bandung: PT. Remaja Rosdakarya.

Erwin dan Becky. (2014). Personal Branding-Inc. Jakarta: PT.Gramedia Pustaka Utama.

Dailey. (2009). Peculiarietes of Social Media Intergration Into Marketing Communications. Dubuque: LA Brown \& Benchmark.

Haroen, Dewi. (2014). Personal Branding Kunci Kesuksesan Anda Berkiprah Di Dunia Politik. Jakarta: PT.Gramedia Pustaka Utama.

Kuswarno, Engkus. (2009). Metode Penelitian Komunikasi: Fenomenologi, Konsepsi, Pedoman dan Contoh Penelitianya. Bandung: Widya Padjajaran.

Moleong, Lexi J. (2007). Metode Penelitian Kualitatif Edisi Revisi. Bandung: PT. Remaja Rosdakarya. 
Vol. 3, No. 1, Juli 2019, Hal 31-38

Mulyana, Deddy. (2006). Metode Penelitian Kualitatif. Bandung: PT. Remaja Rosdakarya. 